\title{
Genetic variation and racial admixture in the Miskito of the southern Mosquito Shore, Nicaragua
}

\author{
Jorge Azofeifa ${ }^{1}$, Edward Ruiz ${ }^{1}$ and Ramiro Barrantes ${ }^{1}$ \\ 1 Instituto de Investigaciones en Salud (INISA) and Escuela de Biología, Universidad de Costa Rica, San José, Costa Rica, \\ Central America; Fax: (+506) 207 5130; e-mail: jazofeif@cariari.ucr.ac.cr
}

\begin{abstract}
A survey of the electrophoretic variation at eleven loci red-blood cell enzymes, hemoglobins and serum proteinswas performed on a sample of 59 Miskitos stemming from the southernmost part of the Mosquito shore of Nicaragua. Seven loci, ALB, $\alpha-, \beta-, \gamma$-globins, LDHA, LDHB, and TPI were monomorphic; AP1, CP, HP and TF were polymorphic representing a proportion of polymorphic loci $(\mathrm{P})$ of 0.364 and an average heterozygosity $(\hat{H})$ of 0.077 . Both values are within a range covered by ten Chibchan tribes of Costa Rica and Panama evaluated for the same loci $-(\mathrm{P})=0.364-0.182$; $(\hat{H})=0.104-0.052-$. The data allowed an estimation of minimum $\left(m_{1}=0.0\right)$, mean $\left(m_{m}=7.34\right)$ and maximum $\left(m_{s}=21.9\right)$ percentages of racial admixture with blacks. For comparison, admixture was also calculated from the data -mainly blood groups- of a previous survey performed in 1960 by A. Matson and his group on a sample of a region near the border between Nicaragua and Honduras; results $\left(m_{1}=6.05\right),\left(m_{m}=11.0\right)$ and $\left(m_{s}=18.1\right)$. The values showed no statistical difference, for the mean estimates, under the assumption that the non-Indian alleles are Poisson-distributed $(\mathrm{P}=0.42)$. The documentation of what is supposed to be the beginning of the racial admixture of the Miskito with blacks in 1641 permitted the calculation of the rate of admixture per generation -generation length: 27 years-; its maximum value lies between 1.68 and 1.91 percent. These.results indicate that the Miskito gene pool has a preponderance of features characteristic of Amerindian populations.
\end{abstract}

Key words: Amerindians, Miskito, Nicaragua, racial admixture, genetic polymorphisms.

The Miskito inhabit part of the Caribbean coasts of Honduras and Nicaragua, a broad region known as the Mosquito Shore -also Mosquitia or Miskito Coast-. At the NicaraguansidetheMiskito are the prevailing ethnic group. According to cultural, mainly linguistic and ethnohistorical grounds the Miskito have been considered Amerindians. Besides Miskito, a language of the Misumalpa Family with ambiguous relations to the Phylum Macrochibcha (Constenla 1991) they alsospeakEnglish andSpanish. The total Miskito population was estimated to be around 70900 at thebeginning of the 1980s (DavidsonandCounce quoted by Perez Brignoli 1997).

The origins of the Miskito are unclear; it has been suggested that they are a post-contact group, a fission product of the Sumo after the intrusion of Europeans (Conzemius 1984). Helms (1969) considers them a "colonial tribe", a result of colonial policies, in this case of the English, who having the intention to establish their hegemony in the Caribbean coasts of Central America and the West Indies "created" the Miskito. Newson (1987) places the origins of the Miskito around 1641 when a subgroup of the Sumo began the racial admixture with blacks. Alternatively the Miskito existed as a defined group before the contact with Europeans, a possibility supported by glottochronology studies that reveal a divergence time between the Miskito and the Sumo languages ranging from 4664 to 4252 years (Moreira 1986). 
The archaeology of the region has been only scarcely studied. Perhaps the only systematic works are those of Magnus (1974) who defined four complexes between the North of PearlLagoon and the southern end of the Bluefields Bay dating from Christ to $1200 \mathrm{AD}$. The earliest had characteristics suggesting South American intrusion; the last three are probably of primary local development, an indication that this part of the Caribbean coast of Nicaragua was an isolated region, hence the development of a local culture was feasible; however, the relation of these cultures with the groups documented to have existed there is unknown.

The best ethnohistorical chronicle on the Miskito and the Sumo was published by Conzemius in 1932 (Conzemius 1984). The following brief account is based on it: the earliest contacts of the Miskito with outsiders date back to 1612 and 1630 with French and English buccaneers respectively. Their relations with African-Blacks and its resultant gene flow began apparently in 1641 when a ship transporting slaves ran aground at the Miskito Keys. The inflow of Black genes continued in the eighteenth century when the English brought further slaves from Jamaica. In the following centuries Blacks also came to the Miskito Coast from the Frenchspeaking Antilles, from Central America and from Colombia. During colonial times the Spaniards never had access to the territory and their descendants, mainly mestizo, did not succeed until 1894, when the Nicaraguan Government took possession of the region.

Here we report on a survey of the genetic variation at eleven loci -red blood cell enzymes, hemoglobins, and serum proteins- in the Miskito of the Southern Mosquito Shore of Nicaragua. Previous genetic studies on the Miskito were performed by Matson and his collaborators using blood groups (Matson and Swanson 1963d) and haptoglobin, hemoglobin and transferrin (Matson et al. 1963), studies mainly limited to summarize allele frequencies. Our approach includes estimations of theremaining Amerindian heritage this subgroup still posses using both the results of our screening and for comparison the data of Matson and his group, which indicate that the Miskito gene pool still own an important proportion of Amerindian ancestry.

\section{MATERIAL AND METHODS}

During and after the Sandinist Revolution (1978 1987) many Nicaraguans fled to Costa Rica seeking asylum. Among them there were Miskitos stemming from the southernmost part of the Mosquito Shore at the Caribbean littoral of Nicaragua. The Miskito refugees were allocated at the Pueblo Nuevocamp situated approximately $3 \mathrm{~km}$ Southwest from the downtown of Limon, the most important port in the Caribbean coast of Costa Rica. Fifty nine blood samples were collected in this camp in January 1986 and processed as described elsewhere (Barrantes et al. 1990). At the sampling time there were 750 Nicaraguan refugees, $40 \%$ of whom identified themselves as Miskitos. The rest were $45 \%$ of African ancestry, $14 \%$ Mestizo and 1\% Rama (Diaz and Achi 1989).

Genetic variation at eleven loci was screened by electrophoresis as previously accounted (Barrantes et al. 1990). The loci analyzed were: albumin (ALB), acid phosphatase 1 (AP1), ceruloplasmin (CP), $\alpha-, \beta$ - and $\gamma$-globins, haptoglobin (HP), lactate dehydrogenases A and B (LDHA, LDHB), transferrin (TF) and triose phosphate isomerase (TPI).

Allele frequencies were calculated by gene counting. The proportion of polymorphic loci $(\mathrm{P})$ average heterozygosities $(\hat{\mathrm{H}})$, locus variances $\mathrm{V}(\hat{\mathrm{h}})$ and their total variances $\mathrm{V}(\mathrm{H})$ were estimated according to Nei (1987). A locus was considered polymorphic if its most common allele reached a frequency of 0.99 or less.

Percentages of admixture were estimated after Szathmary and Reed (1978), who developed a method to be applied in small populations where some loci are known to be monomorphic and the 
only present allele at each locus is the same in all populations, as is the case of the $\mathrm{ABO}^{*} \mathrm{O}$, or where certain alleles or haplotypes seldomoccur, e.g. the Rh-Hr*r in Amerindian populations; consequently the detection of foreign alleles at these loci is possible. The method also assumes that the frequencies of the outsider alleles are small and therefore Poisson-distributed, thus allowing the estimation of minimum $\left(\mathrm{m}_{\mathrm{i}}\right)$, mean $\left(m_{m}\right)$ and maximum $\left(m_{s}\right)$ values of admixture. Furthermore, since the African-Black origin of certain alleles is, under determined circumstances, unambiguously definable, as is the case of the $\mathrm{CP}^{*} \mathrm{~A}$, the $\mathrm{CP}^{*} \mathrm{C}$ and always with certainty for the $\beta$-globin responsible for the $\mathrm{HbS}$ trait, admixture with Blacks can also be estimated. In this sample African alleles were expected at the $\mathrm{CP}, \beta$-globin and TF loci. Likewise the data on the $\mathrm{ABO}, \mathrm{Rh}-\mathrm{Hr}, \beta$-globin and TF loci of Matson et al. (1963) and Matson and Swanson (1963d) permitted not only an independent calculation of the African admixture butalso an estimate, based on the ABO, Rh-Hr and TF loci, of the Spanish contribution to the gene pools of the Nicaraguan Miskito, Sumo, Rama, Subtiaba and Chorotega. The data of Barrantes et al. (1985) were used to estimate the Black (ABO, CP, TF) and Spanish (ABO, TF) admixture, in the remaining Costa Rican representants of the Chorotega, settled in Matambu, Province of Guanacaste. The African and Spanish ancestral allele frequencies used were averages of those published by Roychoudhury and Nei (1988).

Additionally, the documentation of what is supposed to be the earliest contacts of Africans with the Miskito around 1641, as quoted by Conzemius (1984), enabled us to estimate the unidirectional rate of admixture per generation into the Miskito gene pool as shown by CavalliSforza and Bodmer (1971). To calculate the number of generations elapsed since 1641 , the generation length of 27 years determined for the Yanomama (Neel and Weiss 1975) was adopted as a good mean approximation to the values that Amerindian aboriginal populations should have attained.

\section{RESULTS}

The allele frequencies at the 11 loci analyzed are summarized in Table 1 . Seven of them, namely ALB, $\alpha$-, $\beta$ - and $\gamma$-globins, LDHA, LDHB and TPI were monomorphic with only one allele. Two other loci, AP1 and HP, showed universal polymorphisms, i.e. with alleles found in almost all human populations, $\mathrm{AP} 1{ }^{*} \mathrm{~A}$ and $\mathrm{AP} 1 * \mathrm{~B}$, and $\mathrm{HP}^{*} 1$ andHP* 2 respectively. TF was polymorphic with three alleles, the ubiquitous $\mathrm{TF}^{*} \mathrm{C}$, the more differentially distributed TF*DGUA, until now only reported in Costa Rican and Panamanian Indians, and $\mathrm{TF}^{*} \mathrm{DCHI}$ common in Amerindian and Asian populations. The CP locus was also polymorphic with the normal $\mathrm{CP}^{*} \mathrm{~B}$ and with $\mathrm{CP}^{*} \mathrm{~A}$ and $\mathrm{CP}^{*} \mathrm{C}$.

TABLE 1

Allele frequencies at eleven loci coding for red-blood ceil and serum proteins surveyed in a sample of 59 Miskitos from the southern Mosquito Shore of Nicaragua

ALB

HP:

$\mathrm{N}=1.000 \quad 1=0.466$

AP1:

$2=0.534$

$\mathrm{A}=0.068$

$\mathrm{B}=0.932$

LDHA:

$\mathrm{CP}$ :

$\mathrm{B}=0.984 \quad 1=1.000$

$\mathrm{A}=0.008 \quad \mathrm{TF}$

$\mathrm{C}=0.008$

$\mathrm{C}=0.898$

DGUA $=0.093$

$\alpha$-globin

$\mathrm{N}=1.000$

$\mathrm{DCHI}=0.008$

TPI:

$\beta$-globin

$=1.000$

$\gamma$-globin

$\mathrm{N}=1.000$ 
Table 2 summarizes this information in terms of the proportion of polymorphic loci $(\mathrm{P})$ average heterozygosity $(\hat{H})$ and their respective locus $\mathrm{V}(\hat{\mathrm{h}})$ and total variances $\mathrm{V}(\hat{\mathrm{H}})$, and offers a contextual perspective of the extent of the genetic variation exposed by the eleven loci analyzed by comparing their estimates for the Miskito with those, based on the same loci, of ten Chibchan groups of Costa Rica and Panama. The Miskito show values within the range covered by the series of populations compared. Remarkably, no singleestimator for the Miskitoexceeds the upper values of the populations compared.

\section{TABLE 2}

Proportion of polymorphic loci $(P)$, average heterozygosites $(\hat{H})$, variance of locus heterozygosities $V(\hat{h})$ and total variances $V(H)$ in the Nicaraguan Miskito and in ten other tribes of Costa Rica and Panama. For comparison the estimates were based on the same eleven loci-see TABLE 1 -

Tribe $(n)^{1}$

$\mathrm{P}$

a) This communication

$\mathrm{V}(\hat{\mathrm{h}})$

$\mathrm{V}(\hat{\mathrm{H}})$

Miskito (59)

0.364

0.077

0.0236

0.0022

b) Data from Barrantes et al.(1990)

$\begin{array}{lllll}\text { Guaymi (561-563) } & 0.364 & 0.104 & 0.0342 & 0.0031 \\ \text { Bribri Atl (164-166) } & 0.364 & 0.101 & 0.0281 & 0.0026 \\ \text { Teribe (62-63) } & 0.273 & 0.091 & 0.0269 & 0.0025 \\ \text { Cabecar Atl (82-83) } & 0.364 & 0.088 & 0.0212 & 0.0019 \\ \text { Bribri Pac (98-99) } & 0.273 & 0.087 & 0.0259 & 0.0024 \\ \text { Boruca (62) } & 0.273 & 0.072 & 0.0240 & 0.0022 \\ \text { Bokota (118-119) } & 0.182 & 0.065 & 0.0251 & 0.0023 \\ \text { Cabecar Pac (59-60) } & 0.273 & 0.064 & 0.0231 & 0.0021 \\ \text { Guatuso (83) } & 0.273 & 0.063 & 0.0221 & 0.0020 \\ \text { Kuna (113-114) } & 0.182 & 0.052 & 0.0139 & 0.0013\end{array}$

\footnotetext{
${ }^{1}$ Number of individuals tested.
} 
Considering that the admixture of the Miskito with Blacks has occurred since the first half of the seventeenthcentury, Africanalleles were expected at the $\mathrm{CP}, \beta$-globin and TF loci. Regarding $\mathrm{CP}$, as this locus is generally monomorphic in Amerindians $(\mathrm{CP} * \mathrm{~B})$ and taking into account that $\mathrm{CP} * \mathrm{~A}$ and $\mathrm{CP} * \mathrm{C}$ are relativelly common in African populations, the presence of the last alleles in the Miskito was assumed to be introduced by Blacks. Thus, minimum $\left(\mathrm{m}_{1}\right)$, mean $\left(\mathrm{m}_{\mathrm{m}}\right)$ and maximum $\left(\mathrm{m}_{\mathrm{s}}\right)$ estimates of Black admixture in the Miskito were calculated (Table 3, part a)). Their values range from a minimum of 0.0 , an unreal one, through a mean of 7.34 to a maximum of 21.9 percent.

\section{TABLE 3}

Estimated minimum $\left(m_{l}\right)$, mean $\left(m_{m}\right)$ and maximum $\left(m_{s}\right)$ percentages of racial admixture with Black and Spanish in five Nicaraguan and one Costa Rican Amerindian tribes.
Blacks
Spanish
Total

Tribe

$\mathrm{m}_{1} \quad \mathrm{~m}_{\mathrm{m}} \quad \mathrm{m}_{s}$

$\mathrm{m}_{1}$

$\mathrm{m}_{\mathrm{m}} \quad \mathrm{m}_{\mathrm{s}}$

$m_{1}$

$\mathrm{m}_{\mathrm{m}} \quad \mathrm{m}_{s}$

a)This communication:

Miskito

$$
(2 / 354)^{1}
$$

$\begin{array}{lll}0.0 & 7.34 & 21.9\end{array}$

b) Data of Matson et al. ${ }^{2}$ :

$\begin{array}{lccccccccccc}\text { Miskito } & (22 / 1158) & 6.05 & 11.0 & 18.1 & (22 / 924) & 4.72 & 8.64 & 14.2 & 5.38 & 9.82 & 16.2 \\ \text { Rama } & (1 / 306) & 0.0 & 1.9 & 7.6 & (1 / 226) & 0.0 & 1.61 & 6.43 & 0.0 & 1.76 & 7.02 \\ \text { Sumo } & (4 / 728) & 0.0 & 3.2 & 7.21 & (4 / 628) & 0.0 & 2.31 & 5.19 & 0.0 & 2.76 & 6.2 \\ \text { Subtiaba } & (9 / 228) & 7.67 & 23.0 & 45.9 & (9 / 172) & 6.32 & 19.0 & 38.0 & 7.0 & 21.0 & 42.0 \\ \text { Chorotega } & (18 / 652) & 8.02 & 16.0 & 27.6 & (18 / 520) & 6.30 & 12.6 & 21.6 & 7.16 & 14.3 & 24.6\end{array}$

c) Data of Barrantes et al. (1985):

Matambu (30/658) $\quad 20.2$

' (Number of non-Indian genes/Number of genes examined), ${ }^{2}$ Matson et al. (1963), Matson and Swanson (1963d).

Mean ancestral frequencies (Roychoudhury and Nei, 1988):

African Black: ABO, $f\left({ }^{*} \mathrm{~A}\right)+\mathrm{f}\left({ }^{*} \mathrm{~B}\right)=0.298 ; \mathrm{TF}, \mathrm{f}\left({ }^{*} \mathrm{~B}\right)=0.004 ; \int$-globin, $\mathrm{f}\left({ }^{*} \mathrm{~S}\right)=0.123 ; \mathrm{Rh}-\mathrm{Hr}, \mathrm{f}\left({ }^{*} \mathrm{Rz}\right)+\mathrm{f}\left({ }^{*} \mathrm{r}^{\prime}\right)+\mathrm{f}\left({ }^{*} \mathrm{r}^{\prime}\right)+\mathrm{f}(\mathrm{Ry})$ $=0.263 ; \mathrm{CP}, \mathrm{f}\left({ }^{*} \mathrm{~A}\right)+\mathrm{f}\left({ }^{*} \mathrm{C}\right)=0.104 . \overline{\mathrm{X}}^{\mathrm{a})}{ }_{(\mathrm{CP} . \text { нь. TF }}=0.077$;

$\overline{\mathrm{X}}^{\mathrm{b})}$

Spanish: ABO, $\mathrm{f}\left({ }^{*} \mathrm{~A}\right)+\mathrm{f}\left({ }^{*} \mathrm{~B}\right)=0.3419 ; \mathrm{TF}, \mathrm{f}\left({ }^{*} \mathrm{~B}\right)=0.010 ; \mathrm{Rh}-\mathrm{Hr}, \mathrm{f}\left({ }^{*} \mathrm{Rz}\right)+\mathrm{f}\left({ }^{*} \mathrm{r}^{\prime}\right)+\mathrm{f}\left({ }^{*} \mathrm{r}^{\prime \prime}\right)+\mathrm{f}(\mathrm{Ry})=0.474 . \bar{X}^{\mathrm{b})}{ }_{(\mathrm{ABO} . \mathrm{TF} \cdot \mathrm{Rh}-\mathrm{Hr})}=0.2753$; $\overline{\mathrm{X}}^{\mathrm{c})}{ }_{\text {(ABO.TF) }}=0.176$ 
Forcomparison, percentages of admixture were also calculated on the basis of an independent study performed by Matson and colleagues in 1960 (Matson et al. 1963, Matson and Swanson 1963d). Theirsurveysincluded the Miskito of the border zone between Nicaragua and Honduras nearRio Coco, and other Nicaraguan Amerindian groups, and analyzed a differentseries of markers, mainly blood groups, from that reported here. The estimated admixtures based on this earlier study (Table 3, part b)) range from a minimum of 6.05 through a mean of 11.0 to a maximum of $18.1 \%$ Black genes in the Miskito. The difference between both mean values were not significant under the assumption that the outsider genes are Poisson-distributed ( $\mathrm{P}=0.42)$.

Likewise, Matson's data allowed the estimate of the Spanish contribution. However, since the outsider origin of some alleles cannot be unequivocally ascribed to Black or Spanish (e.g. $\mathrm{ABO}^{*} \mathrm{~A}, \mathrm{ABO}^{*} \mathrm{~B}, \mathrm{TF}^{*} \mathrm{~B}$ ), the estimates presented assume exclusive admixture with either of them. Therefore neither of both estimates is completely accurate; notwithstanding one can be confident that, in the case of the Miskito, that for Black admixture is a good approximation, since the first contactsof the Miskito withpeoplebearing alleles of Spanish ancestry took place in the nineteenth century, nearly two hundred years after their first contacts with Blacks (Conzemius 1984). Moreover, probably the main ways by which Spanishallelescameintothe Miskitowere through secondary admixture, with persons of IndianSpanish,Black-Spanish or Black-Indian-Spanish parentage, events that introduced further Indian and Black alleles. Accordingly, the calculation of both Black and Spanish contributions to the Miskitogenepoolsare undoubtedly overestimated with a more exaggerated effect on that for the Spanish. However, if we look at the estimates of total admixture, they offer an idea of how much Indian heritage the Miskito still posses: the minimum is around $78 \%$ and the mean $93 \%$.

The estimates based on the data of Matson and colleagues indicate a minimum Indian component of about $85 \%$ and a mean of circa $90 \%$. If we consider that both samples were obtained within an interval of 26 years (1960 and 1986), i.e. one generation, and that the markers employed are different, it could be safely admitted that the estimates of total admixture permit a good approximation to the actual value of Amerindian genetic heritage in the Miskito gene pool.

TheRamaandSumo, like the Miskito, probably have a major Black contribution since they also inhabited the Caribbean areas of Nicaragua. On the contrary, the estimates of admixture with Spanish are probably mostaccurate in the Subtiaba and Chorotega, for their ancestors had closer relations with Spaniards than with African Blacks; however, the best approximations of admixture are, again, the proportions of the remaining Amerindian component derived from the estimated percentages of admixture. Thus, those with less Indian heritage were, around 1960, the Subtiaba with a minimum of $58 \%$ to a maximum of $93 \%$. On the otherhand, the Rama were the less mixed with a minimum of $93 \%$ to an untrue maximum of $100 \%$.

Table 3 also shows a comparison of admixture between two groups whose people identify themselves as Chorotega, one settled at Santa Isabel, Leon, Nicaragua and the other located in Matambu, Guanacaste, CostaRica.Althoughboth estimates are derived from independent studies with an interval of 15 years between them (1960 and 1975 respectively) and based on different loci, the values obtained allow to conclude that the CostaRicans (19-51\%) haveintegratednearly twice as much non-Indian genes in their gene pool as the Nicaraguans (7-25\%).

The pace at which the Black admixture has taken place in the Miskito was calculated (Table 4) from the two estimates presented in Table 3. The number of generations elapsed since 1641 differs between both series, comprising 12.8 generations for the survey reported here. The values varied according to the extent of admixture considered $-\mathrm{m}_{\mathrm{l}}, \mathrm{m}_{\mathrm{m}}, \mathrm{m}_{\mathrm{s}}$ - but reached a maximum of $1.91 \%$ per generation. The data of Matson and his group embody 11.8 generations and their 
corresponding rates of admixture per generation go up to a maximum of $1.68 \%$.

\section{TABLE 4}

Black-African admixture rates per generation in the Miskito since 1641 based on the minimum $\left(m_{1}\right)$, mean $\left(m_{m}\right)$ and maximum $(m)$ percentages of admixture estimated from two independent studies and assuming a generation length of 27 years.

\begin{tabular}{|c|c|c|}
\hline a) $1641-1986^{1 /}$ (i.e. 12.8 generations) & $\mathrm{m}_{\mathrm{i}}$ & $\mathrm{m}_{\mathrm{m}}$ \\
\hline Cumulated rate $(\%)$ & 0.0 & 7.34 \\
\hline Admixture per generation & 0.0 & 0.59 \\
\hline b) $1641-1960^{2} /$ (i.e. 11.8 generations) & $\mathrm{m}_{\mathrm{i}}$ & $\mathrm{m}_{1}$ \\
\hline Cumulated rate $(\%)$ & 6.05 & 11.0 \\
\hline Admixture per generation & 0.53 & 0.98 \\
\hline
\end{tabular}

Sources of gene frequencies: ${ }^{1}$ This communication; ${ }^{2}$ Matson et al. (1963), Matson and Swanson (1963d)

\section{DISCUSSION}

The disclosure of the genetic structure of a population through allelic variation offers the possibility to infer part of its evolutionary history. The ideal situation should allow to determine genetic distances among populations whose relative isolation shouldhaveresulted in a certain degree of differentiation. Human populations posses the additional advantage that genetic phylogenies can be evaluated in cultural, i.e. archaeological and ethnological contexts, with respect to geographical parameters, andcompared also with linguistic relations.

Howevercertain evolutionary events, like gene flow among populations, deviate from the ideal conditions to estimate genetic distances. Considering this Cavalli-Sforza et al. (1994) excluded all populations with $25 \%$ or more admixture from their compendium of genetic diversity of the majorhuman groups of the world. The Miskito have received non-Indian alleles, mainly African Black, since at least the first part of the seventeenth century, an inflow evident on the phenotypic appearance of most individuals. The loci screened in this study uncovered part of this unidirectional racial mixture. The extent of this admixture, as also estimated from the data of Matson et al. (1963) and Matson and Swanson (1963d), indicates that any attempt to solve the real taxonomic situation of the former Miskito based on genetic markers would be to a great extent misleading. Moreover, the phylogenetic approach is further limited by the fact that most of the Miskito's neighbor tribes of Mesoamerican filiation are also mixed to a great extent as was observed in the Chorotega and as is to infer from the presence of non-Indian alleles in other Central American and Mexican groups (Matson and Swanson $1963 \mathrm{a}, \mathrm{b}, \mathrm{c}$ ). Therefore, the hypothesis that the Miskito are not a postcontact product cannot be validated in genetical terms and must rely only on linguistic grounds (Moreira 1986, Constenla 1991). Additionally, during the Miskito domination of other Central American Indian groups, the Miskito should have incorporated genes from the submissed tribes into its gene pool. The detection of these admixtures and the estimation of their extent is impossible and the phylogenetic analysis would probably show an artifactual correlation with geographic proximity instead of their actual evolutionary relations. Notwithstanding the Miskito as an important and influential culture are a reality and any attempt to characterize its genetic constitution is worth.

Regarding the estimates of variation $(\mathrm{P}, \mathrm{H})$ presented here, it must be kept in mind that they should be seen only as a reference to put in perspective the values, basedon 11 loci, observed in the Miskito. It is obvious that such estimates approach their real values as the number of loci screened per population increases. Therefore better estimates, based on 39 loci, were previously calculated for the ten groups taken as parameters (Barrantes 1993). Their values were lower than those obtained here, a result to be expected considering the reduced heterozygosity characteristic of Amerindian populations (Neel 1978). 
In this context, two considerations are to be made when interpreting the rates of admixture per generation, first, they are assumed to be constant in time, and second, that the generations are discrete. Although both presumptions are not exactly realistic, the estimates indicate a slow replacement of the former Amerindian Miskito gene pool; for instance, Black-Americans should have received a Caucasian gene infusion of $3.5 \%$ per generation for a period of 10 generations (Cavalli-Sforza et al. 1994) more than twice that obtained for the Miskito.

The results of the genetic study of the 11 loci presented here put a lower limit of residual Indian genes of approximately $80 \%$ in the Miskito of the Southern MosquitoShore. In addition the presence of alleles like TF*DGUA and TF*DCHI and the fact that the proportion of polymorphic loci and the average heterozygosities do not lie outside the magnitudes found in less mixed Amerindian groups argue for the validation of the Miskito as Amerindian.

\section{ACKNOWLEDGMENTS}

We thank J. Gamboa for his help in the field and laboratory and G.Gutierrez for providing us literature. This research was supported by the Universidad de Costa Rica (Program 742-88065) and by the Consejo Nacional de Investigaciones Científicas y Tecnológicas de Costa Rica (CONICIT).

\section{RESUMEN}

Se estudió la variación electroforética de 11 loci que codifican para enzimas eritrocíticas, globinas y proteínas séricas en una muestra de 59 indígenas misquitos originarios de la región sur de la Mosquitia de Nicaragua. Siete loci, ALB, à-, $\int-y \partial$-globinas, LDHA, LDHB y TPI fueron monomórficos, mientras que AP1, CP, HP y TF fueron polimórficos. Esto se traduce en una proporción de loci polimórficos $(\mathrm{P})$ de 0.364 y una heterocigosis media $(\mathrm{H})$ de 0.077. Ambos valores se encuentran dentro del ámbito de variación mostrado por diez grupos indígenas de estirpe chibchense de Costa Rica y Panamá evaluados para los mismos loci $[(\mathrm{P})=0.364-182,(\mathrm{H})=0.104-0.052]$. El análisis permitió una estimación de los porcentages mínimo $\left(\mathrm{m}_{1}=\right.$ $0.0)$, medio $\left(m_{m}=7.34\right)$ y máximo $\left(m_{s}=21.9\right)$ de mezcla racial con negros. A manera de comparación, esta mezcla se calculó también a partir de los resultados de A. Matson y su grupo, quienes estudiaron, en 1960, la variación genética, usando primordialmente grupos sanguíneos, en una muestra de misquitos de la región fronteriza entre Nicaragua y Honduras. Los resultados $\left(m_{1}=6.05\right),\left(m_{m}=11.0\right)$ y $\left(m_{s}=18.1\right)$ no fueron diferentes estadísticamente, para los valores medios, bajo la suposición dequelos alelos no-indígenas siguen la distribución de Poisson ( $\mathrm{P}=0.42)$. Además, la disponibilidad de una fecha en la que se supone se inició la mezcla de los mísquitos con negros, en 1641, permitió el cálculo de la tasa de mezcla por generación. Dada una duración generacional de 27 años, su valor máximo se encuentra entre el 1.68 y el $1.91 \%$. Estos resultados indican que el acervo genético de los mísquitos aun conserva características propias de los grupos amerindios.

\section{REFERENCES}

Barrantes, R. 1993. Diversidad genética y mezcla racial en los amerindios de Costa Rica y Panamá. Rev. Biol. Trop. 41: 379-384.

Barrantes R., J. Azofeifa \& L.Mata. 1985. Grupos sanguíneos $\mathrm{ABO}$ y Rh y proteínas séricas en una población amerindia, Matambú, Costa Rica. Rev. Biol. Trop. 33: 13-16.

Barrantes R., P. E. Smouse, H. W. Mohrenweiser, H. Gershowitz, J. Azofeifa, T.D. Arias \& J.V.Neel. 1990. Microevolution in Lower Central America: genetic characterization of the Chibcha-speaking groups of Costa Rica and Panama, and a consensus taxonomy based on genetic and linguistic affinity. Am. J. Hum. Genet. 46: 6384.

Cavalli- Sforza, L. L. \& W. Bodmer. 1971. The Genetics of Human Populations. W.H. Freeman, San Francisco. 965p.

Cavalli-Sforza L.L., P. Menozzi \& A. Piazza. 1994. The History and Geography of Human Genes. Princeton University, New Jersey. 541p. + 526 maps.

Constenla, A. 1991. Las Lenguas del Area Intermedia: Introducción a su Estudio Areal. Universidad de Costa Rica, San José, Costa Rica. 216p.

Conzemius, E. 1984. Estudio etnográfico sobre los indios Miskitos y Sumus de Honduras y Nicaragua. Asociación Libro Libre, San José, Costa Rica. 336p. (Translated by J.Incer from the original English version of 1932 "Ethnographical survey of the Miskito and Sumu Indians 
of Honduras and Nicaragua". Smithsonian Institution Bureau of American Ethnology. Bulletin 106. Washington, D.C.).

Diaz, T. \& R. Achi. 1989. Infectious diseases in a Nicaraguan refugee camp in Costa Rica. Trop. Doctor 19: 14-17

Helms, M.W. 1969. The cultural ecology of a colonial tribe. Ethnology 8: 76-84.

Magnus, R.W. 1974. The prehistory of the Miskito Coast of Nicaragua: a study in cultural relationships. Ph.D. Thesis. Yale University, Connecticut.

Matson, G.A. \& J. Swanson. 1963a. Distribution of hereditary blood antigens among Indians in Middle America. II. Tzotzil and other Maya. Am. J. Phys. Anthrop. 21: 1-14.

Matson, G.A. \& J. Swanson. 1963b. Distribution of hereditary blood antigens among Indians in Middle America. III. In Guatemala. Am. J. Phys. Anthrop. 21: 301-318.

Matson, G.A. \& J. Swanson. 1963c. Distribution of hereditary blood antigens among Indians in Middle America.IV. In Honduras. Am. J. Phys. Anthrop. 21: 319-333.

Matson, G.A. \& J. Swanson. 1963d. Distribution of hereditary blood antigens among Indians in Middle America. V. In Nicaragua. Am. J. Phys. Anthrop. 21: 545-559.

Matson G.A., H. E. Sutton, J. Swanson \& A. R. Robinson 1963. Distribution of haptoglobin, transferrin and hemoglobins types among Indians of Middle America: Southern Mexico, Guatemala, Honduras and Nicaragua. Hum. Biol. 35: 474-483.
Moreira, Y. 1986. Análisis Lexicoestadístico de las Relaciones entre el Cacaopera, Matagalpa, Sumo Septentrional, Ulua y Misquito. Tesis de Licenciatura en Lingüística. Universidad de Costa Rica, San José, Costa Rica. 45 p.

Neel, J.V. 1978. Rare variants, private polymorphisms and locus heterozygosity in Amerindian populations. Am. J. Hum. Genet. 30: 465-490.

Neel, J.V. \& K. M. Weiss. 1975. The genetic structure of a tribal population, the Yanomama Indians. XII. Biodemographic studies. Am. J. Phys. Anthrop. 42: 2551.

Nei, M. 1987. Molecular Evolutionary Genetics. Columbia University, New York. 512p.

Newson, L. 1987. Indian Survival in Colonial Nicaragua. Oklahoma University, Norman and London. 466p.

Perez Brignoli,H. 1997.Estimaciones de la poblaciónindígena de América Central (del siglo XVI al siglo XX) p. 25-35. In Rosero L., A. Pebley \& A. Bermúdez (eds.). De los Mayas a la Planificación Familiar. Demografía del Istmo. Universidad de Costa Rica, San José. Costa Rica.

Roychoudhury, A.K \& M. Nei. 1988. Human Polymorphic Genes. WorldDistribution. Oxford University, New York. $393 \mathrm{p}$.

Szathmary, E.J. \& T. E. Reed. 1978. Calculation of the maximum amount of gene admixture in a hybrid population. Am. J. Phys. Anthrop. 48: 29-34. 